\title{
invotec
}

The International Journal of Technical and Vocational Education

UPI JOURNAL

Available online at http://invotec.fptk.upi.edu

\section{Efforts to Enhance the TVET Teachers Competencies through Apprenticeship Approach Pattern in Industry}

\author{
I. W. Ratnata \\ Department of Electrical Engineering Education, Faculty of Technology and Vocational Education, Universitas Pendidikan Indonesia
}

\section{ARTICLE INFO}

Article history:

Received 21 September 2014

Received in revised form 16

August 2015

Accepted 13 November 2015

Available online 11 December 2015

\section{Keywords:}

Vocational teacher education

Apprenticeship approach

Corresponding author:

I_wayan_ratnata@yahoo.com

\section{A B S TR A C T}

Facing ACFTA (ASEAN - China Free Trade Area) in 2015 (ASEAN 2012), nations in the region must be ready with variety of challenges that will occur. In this paper will be focusing how to prepare vocational teachers who will teach in vocational education in order to produce skilled graduates are ready for work and appropriate to the demands of the world of company or industry. Up to now, the existence of vocational teacher education in the region ASEAN-China (RCP:2012) need to be improved, primarily in teaching learning process and need to have enough experience in company or industry. Indonesia is one of the member of the ASEAN's Countries still experiences difficulty to improve vocational teachers' education in order to be ready to teach. The most difficult in preparing of vocational teacher education is in terms of their skill. This study was using case study method, in which data collected through interview in depth to students in Department of Electrical Engineering Education, Faculty of Vocational and Technology Education, Universitas Pendidikan Indonesia. According to the questionnaire done to vocational teachers, students who are doing teaching practice in vocational school, can be concluded that enhancing the quality of vocational teacher education cannot just be provided through theory and should also be provided chance students doing apprenticeship in the world of industry or workplace. In this regard, seemingly it is necessary to have a breakthrough for increasing the students competencies in order fresh araduates are readv for work. 


\section{Introduction}

Entering the era of the ASEAN Economic Community, AEC (ASEAN Economy Community, AEC) in 2015 (RCP, 2013), where there will be tough competition in the ASEAN region include competition not only in the industrial sector but also in the manufacture of human resources. According Sunaryo Kartadinata, Sindo, 17 April 2014, the development of a nation can be seen how the development of its education. Responding to this regard, the education actors must effort seriously to improve the quality of education in order that graduates produced have good qualification and are able to compete with other developed nations.

Minister of Education and Culture (Education), Muh Nuh (Sindo, June 26, 2013: 5), said that Indonesia needs 39,000 vocational teachers to teach vocational field. It was said also that the number of state and private vocational schools spreading throughout Indonesia today are as many as 10,250 vocational schools, while the number of existing vocational teachers are as many as 165,400 teachers, but only $22 \%$ alone are productive teachers (vocational field), in which should be the number of productive teachers is $50 \%$ of the number of existing teachers and he added that not all graduates produced by Colleges or vocational teacher education can teach vocational teacher. Polytechnic graduates (D4, Diploma 4) that are better able to teach in TVET (SMK). Listening to the statement of educational ministery that the teacher colleges that have Faculty of Technology and Vocational Education can be defined not have good skills in the field of vocational teaching in SMK. Means there is something wrong in learning in vocational teacher education. Seeing this condition seems teacher educational institute (LPTK, lembaga pendidikan tenaga kependidikan) should endeavor to prepare and conduct productive teachers who have professional skills in the field.

Apprenticeship is a learning model that has been known and applied for years ago in some countries for enhancing the skills of someone to be ready for work (INAP Commission 2012). It is also stressed that the implementation of Apprenticeship in every country of course there are differences depending on the policy of the local country. The same thing is said Masriam Bukit (2012) in which the competence and skills of TVET teachers is largely determined by how much they get real experience in the working world. So as technology and vocational education teachers get hands-on experience in the world of work in the form of knowledge and skills is something important to be transmitted to the students in the school.

Teacher Education Institute that produces graduates to teach in secondary vocational school (SMK, Sekolah Menengah Kejuruan) has a central role in providing input and help to develop vocational education. From the results of the RCP report (2013) that by the increasing demands of college graduates going to produce skilled manpower and ready to work, the pattern of learning needs to have relevance to the existing activities in the world of industry in the sense that the students carry out activities according to their field of industry practice and sufficient time duration to acquire skills. As known, almost all of the world of education can be said that they don't have a practice facility like the one in the industry (in terms of both number and sophistication), therefore the world of education, especially vocational and technology education should be working together with the world of business and industry so that students can apply the knowledge that has been obtained in college / classroom.

The issue is still being experienced by students in carrying out the industrial practice is not yet clearly visible the pattern of implementation of good industry practice orderly manner and still impressed formality. When examined in depth for vocational teaching staff must have reliable vocational competence to be able to work as a vocational teacher. From the results of the research of vocational education experts in container RCP that the vocational skills of the teaching force $(R C P, 2013)$ must have competence in accordance with the field.

Improving students' ability to practice (skills) and knowledge workforce can only be done through direct experience working in the world of work / business or industry. Problems faced by students is in which students are still difficult to get a chance in doing industry practice (internship) according to their expertise, but unfortunately the amount of industry to accept students for attending internships is not comparable. Students carry out an internship in the industry are generally not more than two months. Ideally students doing industry practice (internship) is not less than 6 months to be able to understand the patterns of employment, industrial atmosphere (environment), skills and insights need to know students. This situation is still regarded one of the obstacles to enhance students's skill within the world of business and industry. 
According to Anang Tjahjono, Director of the Directorate of Vocational Education and Culture Ministry at Rembuk Nasional SMK (TVET national consultation ) events for Developing Nations conducted in the UPI (2012), expressly says that the world of education should build cooperation with the industry, due to the existence and application of existing technologies in the world of work / industry. Cooperation with industry can be done starting from doing industry practice, internship / apprenticeship, research (research) etc. The same thing was stated by TVET expert, Masriam Bukit (2012: 120), TVET teacher mostly do not have an industrial background, and during their service time as teachers in TVET school, they almost never have the opportunity to experience the world of work. Noting the statement clearly the experience of teachers in the world of work and industry is very minimal as the provision of teaching in vocational schools, and this condition needs to have serious attention for higher educations that produce TVET teachers.

\section{Vocational Teacher Competence}

Roles and responsibilities of a teacher is not easy primarily as a professional teacher. A teacher must have a basic competence is to educate. Within educational process is contained elements of teaching, giving an example of a good role model behavior for the development of students. So many components that affect the quality of education, but it is not possible effort to improve the quality of education by improving each of these components be done simultanly or at the same time.

Components that have been considered greatly affect the learning process is the teacher. It is perfectly natural, because the teacher is spearheading that relate directly to students as subjects and objects of study. However good and ideally a curriculum and educational facilities and infrastructure, without being balanced with the ability of teachers to use or implement it, then everything will be in vain (not going to improve the quality of education).

Referring to the Law of Teachers and Lecturer in Indonesia Republic, year 2005, competences that must be owned as educators are:

1) Pedagogical competence; A teacher must be able to transfer the knowledge to the students so that students easily grasp and understand. In association with the approaches, methods, strategies and teaching aid used by teachers in teaching to be really appropriate to its function. For example, the teacher explains the concept of electric current. A teacher uses appropriate methods to explain it and what teaching aid is easy to use. Now, with the advancement of digital technology teachers is not much difficulty in explaining to the students due to the computer help teacher can visualize any model that is difficult to imagine by students.

2) Professional Competence: A teacher must have professional skills in accordance with his / her field. For example, electrical engineering education teachers must have knowledge in the field of electrical engineering and skills in the field of electrical engineering. Examples of a teacher who teach electrical installation techniques, he must understand the concepts of electrical installations in depth and detail, besides that he should be able to teach correctly to the students. He does not feel awkward in teaching and role models of the student.

3) Social Competence. Teacher is not only teaching in the classroom / school, he should be able to be social, love to each other, help each other, in the community. The role of teacher in society that is large enough to be a role model to the community in the form of goodness in educating children, etc..

4) Competence personality. In carrying out duties as a teacher, he must demonstrate respectful manner, not arrogant, humble, always respect the opinions of others. In addition, a teacher never felt quickly satisfied with the knowledge they have learned and always want to find the latest to be delivered to others.

Improving the quality of vocational graduates, one of the key factors is the quality of teachers / educators who function in education. For teacher educational institute (LPTK) is institution as a producer of teachers in which the out put should have a holistic capability, in this respect they have, competencies: pedagogy, professional, social, and personality as mentioned above. Of course, the capability cannot just solely be obtained through theory, and it is definitely obtained from outside the campus, namely internship that is done by the students. 
Quoting the statement from rector UPI, Sunaryo Kartadinata (PR Daily, 25-6-2014), entering the 21st century teachers' role in building the character of the nation and improving the quality of human resources becomes increasingly great. From these statements it is understood that the quality of teacher educators should be improved so that this country, Indonesia can produce the young generations who have a strong and good morals. When associated to the era of ASEAN Economic Community (AEC) in which human resources as main key to compete to other countries.

The pattern of industrial practice activities undertaken to achieve student competence in the field, particularly in Electrical Engineering Education is where students since the beginning, starting from register, determining location for industry practice, determining supervisor or guide or mentor, doing industry practice, processing monitor, drawing up reports, and attending exam. Overall the above steps must be well done. well.

In the process of learning a teacher must have a special ability, an ability that is not owned by the person who is not a teacher. In line with it, a vocational teacher must have good skill as skilled workers. If quoted the statement in INAP Commission, 2012: 7, in which skilled workers must have : (1) creativity (creativity), (2) clarity (clearness / presentation), (3) the ability and concern for the environment (environmental compatibility), (4) social care (social acceptibility), (5) functionality (functionality), (6) work orientation and businesses (business and work process orientation, (7) sustainability / usefulness (sustainability / utility), (8) the efficiency /effectiveness (efficiency / effectiveness).

The attributes outline in fig bellow represent eight-dimensions which skilled workers have to match up to in undertaking a work task (INAP commission 2012).

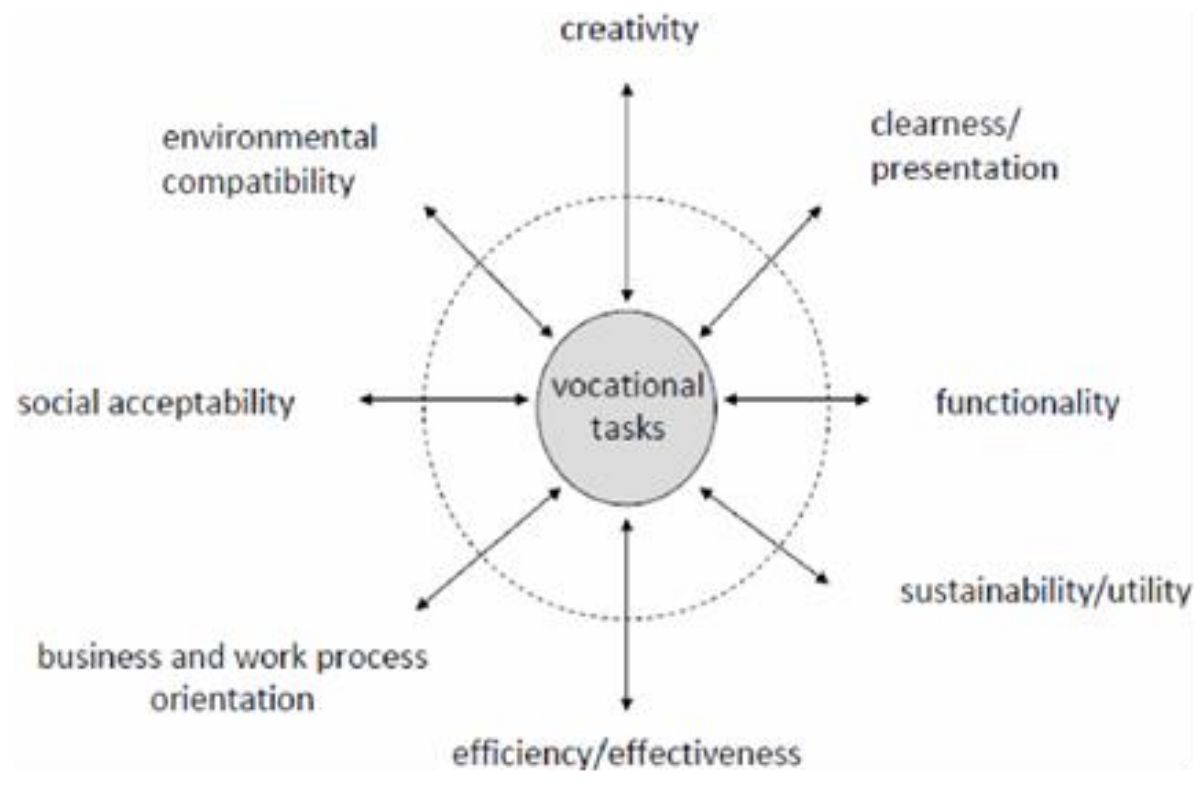

Figure 1: Attributes of the holistic (complete) solution of occupational / professional task to high quality standard.

(Source: INAP Commission, Architecture Apprenticeship 2012: 6)

On the basis of the above thought, professional vocational teachers, where teachers must have the knowledge and ability of eight professional tasks thoroughly and in synergy with each other, as well he should have adequate knowledge in his/her field.

\section{Enhancing Teacher competencies Through Apprenticeship}

According to the development technology right now, demands of professional educators in the field of vocational education is urgent. The role of vocational educators (vocational teachers) in this case is not only required but also able to master technology but the more important is to have considerable skills as an instructor in practical activities. Teacher candidates produced by Vocational teacher education Institutions 
must understand the scope of work that is in the world of work / industry and have adequate skills in the field of expertise.

Speaking of skills related to the competence, students must work well at workshop / laboratory and work practice/ internship in the industry. Given the vocational education students in general practice activity in lab / workshop, and of course these measures constitute an initial step that need to be done by students before performing industrial practice / internship. There are some approach that we have known related to the student industrial practice are: Industry Based Learning (IBL) held at Swinburne University in Australia; Production Based Education and Training held in ATMI Michael Surakarta and Polytechnic Manufacture (Polman) in Bandung; Industrial Incubator Based Learning (IIBL) of Alva Edy Tontowi research results; And Apprenticeship approach. Apprenticeship approach is actually a model of education that has long been applied in western countries for vocational education and has now made the renewal to be a good maximal system.

\section{a. Traditional Apprenticeship}

According to a study published by the standardization body of training (Training Standards Council: 2000), a traditional apprenticeship is a form of apprenticeship in which a person learns a particular expertise in people who are experts in their field. Internships like this, students (children) started its activities by helping at the simplest level to the experts (the owner), and the longer they are given tasks / responsibilities are greater, and doing work like that done by experts. For example: gold artisan crafts, sculpture stonecutters, builders etc.

Generally, to be able to work independently and experts in the field requires a long time even could reach 5 to 7 years. Traditional apprenticeship system prefers handcraft to knowledge or reasoning. So that in general students after participating in a traditional apprenticeship they only know one area of expertise and their progress not rapid as well. As a result, traditional apprenticeship system gradually abandoned by the younger generation, and they are turning to formal education models that enable them to continue their education to a higher level.

\section{b. Modern Apprenticeship}

According to a report published by the Training Standards Councils (2000), published in English, which is explained in the text, that more and more young people want to follow the job training in accordance with the demands of the workplace with the qualification standards is required. By modern apprenticeship system that balances structured learning material vocational qualifications (vocational qualification) and academic knowledge. In these activities are clearly organized structure throught he curriculum which can improve students' competence.

Modern apprenticeship system was introduced in 1995 was redesigned from the traditional apprenticeship system (European Commission, Apprenticeship Supply in the Member States of the European Union, 2012). The term apprenticeship is still maintained in which students still doing activities practices in the industry. With the apprenticeship words indicate that the student has had experience working in the industry so the industry communities will have the notion that vocational education graduates are ready for work. A highly significant difference between modern and traditional apprenticeship, is the duration of the execution time. Traditional apprenticeship time is less clear and tends very long time to one area of expertise. Modern apprenticeship has a scope wider and each element (section) has a clear framework. Why is that? Because of technological developments in the industry very quickly and students should be able to follow it.

The key to success is an important part of all the modern apprenticeship framework adapted to the presence of training in each country, by following the rules, criteria and levels to meet the demands of the world of work and industry. Through a system of Dual Vocational Education (Apprenticeship) will produce human resources that have a high quality and comprehensive in the field of work and skill shown in its certification form, which has the knowledge and skills professionally (INAP Commission, 2012: 5). This education system initiate to form the people who are able to work independently in accordance with the specified standards of the job profile.

Capabilities expected of graduates of vocational education, in addition they are able to communicate well, also have a balance between cognitive knowledge and skill. The condition can be implemented because it is taught by professional instructors in their field. The existing learning process must have a good curriculum 
structure with the linking of theory and practice in an integrated and consistent. Consistent in the sense is the availability of adequate teaching materials, availability of materials and equipments for practices in school, the implementation of apprenticeship in the industry which were all conducted with reference to the rules of the vocational pedagogy.

The dual system of vocational education which is also called the apprenticeship system approach is the incorporation of learning activities in schools with in the world of work. According INAP Architecture Apprenticeship Commission, 2012, there are four important things to note in the dual system:

1) Better coordinating between the vocational education and training (VET) systems and employment / labor market systems.

2) Promoting employment opportunities for young people, Thus facilitating the transition from school-towork.

3) Improving the competitiveness of companies.

4) Opening up rewarding careers for a large segment of the population (INAP Architecture Apprenticeship Commission, 2012).

Related to the of pattern learning approaches of vocational education in Indonesia, as mentioned earlier in which there are two approaches that have been successfully implemented for the vocational education, ATMI Michael in Surakarta (Solo) and Manufacture Polytechnic in Bandung. Judging from the learning activities conducted, actually those educational institutions using approaches Production Based Education and Training (PBET). This model is almost similar to the dual vocational education and training or modern apprenticeship. In PBET learning activities where the number of hours of theory in the classroom is $33 \%$ and $77 \%$ for practice activities. The pattern approach as follows:

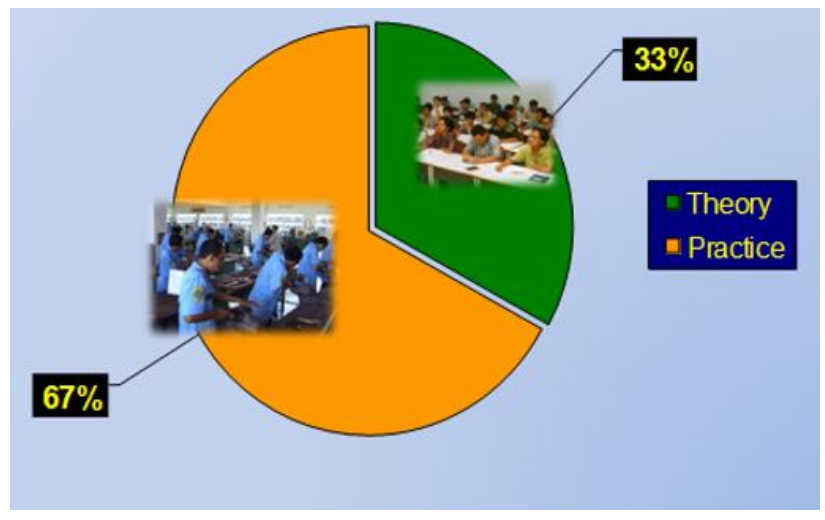

Figure 2: Comparison of the percentage of theoretical lessons and practice (Source: ATMI Polytechnic Surakarta)

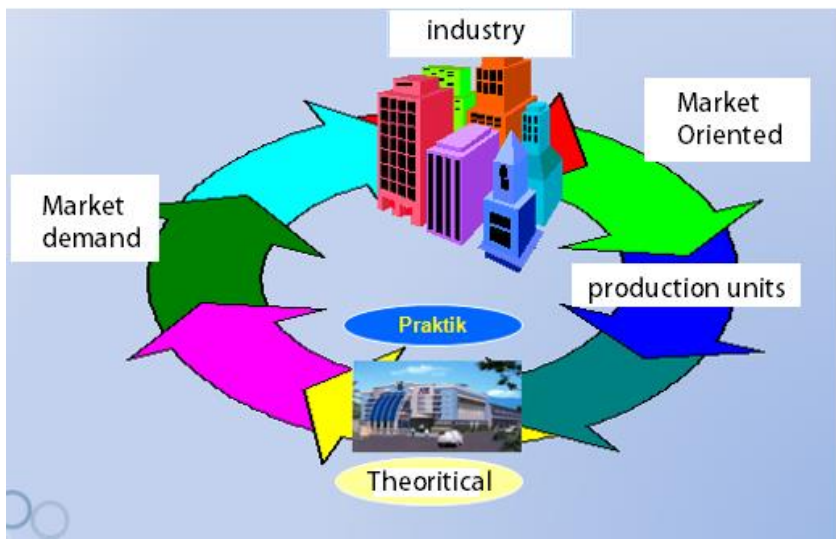

Figure 3: The pattern of PBET activity in ATMI Michael Surakarta (Source: ATMI Polytechnic Surakarta) 
Approach Pattern as implemented in ATMI is in principle the same as the Bandung Manufacture Polytechnic. Through this approach the learning activities of students at the institution is very effective where the student doing real activity in producing tools that are ready to be marketed. Starting from the first semester students are introduced on the pattern of employment in the industry and to the final level student doing practical activities, in which Polytechnic ATMI Surakarta has a production unit capable of producing the goods. Through PBET pattern is able to produce graduates ready to work in accordance with the competence of study field.

Various attempts have been made the government in improving human resources ready to work according to the demands of the workplace. Vocational school graduates and college graduates can attend training at the Training Center facilitated by government. Actually, in Indonesia has some vocational training centers spreading throughout Indonesia (Sindo, 3 September 2014: 3). These institutions can be utilized to improve the skills of students through the program activities of industrial practice.

Related to the efforts to improve the competence of vocational educators ready to work, when viewed from the existing approaches seems a very appropriate apprenticeship modern pattern to be implemented. An educator must have extensive knowledge and good competence and as a model to be shown to students. When associated with the formation of competencies required of an educator, the attributes of a comprehensive solution of professional tasks should be possessed by teachers or instructors.

\section{Methodology}

This paper was prepared on the basis of the conditions in the field (vocational school) in which novice teachers in vocational and when they commenced to work a lot of difficulties they met in the field of vocational (skill). And of course what Mr. Muh Nuh ( Education and Culture Ministry of Indonesia) said, that graduates of polytechnics is more ready to teach vocational field than that of vocational teacher educational graduates can be understood. Talking about the appropriate approach to improve students' skills of vocational education of course its scope is very broad. In this case the author tries to provide a view pattern of Apprenticeship approach that may improve the knowledge and competencies of graduates of vocational teacher education to be ready for work as a vocational teacher. Apprenticeship approach is applied to every country not entirely the same, and its implementation in accordance with existing cultural background (ANAP Commission, 2012). For this approach, of course Apprenticeship in Indonesia is different from the pattern applied in other countries. The author notes that the apprenticeship approach implemented in Indonesia is still limited to the students carrying out internship / industrial practices in the workplace.

In drawing up this paper, the authors conducted interviews with several students of Electrical Engineering Education Department has implemented an internship / industrial practice. Moreover, the authors also intensively ask students who are doing teaching practice in several vocational schools in the Municipality of Bandung and West-Bandung Regency. Moreover, the authors also conducted visitation to several schools, namely SMK Negeri 4 Bandung, SMK Negeri 9 Bandung, SMK Mikael Surakarta, Polytechnic ATMI Surakarta and Polytechnic Manufacturing Bandung from March and April 2012 and Vocational Training Centers (BLK) in Bandung. From the data that was collected and analyzed by using descriptive methods. From the findings were conducted study / discussion with some experts in accordance their field of vocational education. After that, it can be drawn conclution related to pattern of approaches to improve the competence of TVET teachers.

\section{Results and Discussion}

From the theoretical study, interviews with students who had done in industrial practice (internship) and teaching exercise, visited Polytechnic ATMI Surakarta and Polytechnic Manufacture -Bandung that had implemented Production Based Education and Training, (PBET) and is associated with efforts to improve TVET teacher competence in the field of vocational teaching. In this respect it needs exist a proper solution of vocational teachers in accordance with the needs in secondary vocational schools (SMK). Approach pattern in order to fit the needs for vocational educators can be explained as follows:

a) Taking into consideration the industry practical activities of Electro Engineering Education students at workplace, basically they can perform activities of industry practice, and they got lots of experience that they didn't get previously in university. Unfortunately many students in conducting industrial practice, didn't perform activities in industry accordance with their study field background, so that the experience they had is not relevant, and of course its result not optimal. 
b) A vocational educator who is able to do the work (tasks) professionally should have: creativity, clearness / presentation, environmental compatibility, social acceptibility), functionality), business and work process orientation, sustainability / utility, effisiency / effectiveness (INAP Commission, 2012).

c) It appears, that in the modern apprenticeship approach that has been applied in western countries such as Switzerland, Germany and Australia (INAP Commission 2012) has given good results for learners skills. In connection with the preparation of teachers to teach and as an instructor, the benefits industry practice done vocational education students is very important, given the prospective educators must master the knowledge of macro and be able to apply into daily life are used as a model for vocational students.

d) Talking about the existence of the laboratory, where the laboratory is the spearhead in the context of vocational learning in order to produce educators who have competence in accordance with their field of study. Students should be given the opportunity and given the task to undertake best practices. School infrastructure, school facilities to support the theory and practice of learning activities should represent the existence of a vocational school in accordance with the provisions, namely: school should be comfortable, a place of learning theory is equipped with a variety of media that can support the learning process, laboratory / workshop complete with equipment and material for practice.

e) In carrying out practical activities in workplace, many of which can be obtained by students, such as students gain the knowledge and insight that there is no in the class will be found in the world of work is begun discipline, work on time, fostering creativity, mutual respect to each other and having responsibilities and all of that constitute important aspects or components of soft skills that must be undergone students in the world of work.

\section{Conclusions and Recommendations}

From the results of studies on efforts to improve the competence of TVET teachers through apprenticeship approach pattern can be concluded as follows:

1) Setting up of vocational educators to be able to teach according to their study field where they should have sufficient competence. An educator should have professional competence namely: pedagogy, professional, social and personality in which the competencies not only acquired at the university but also acquired through real activities in the real work at industry or workplace called apprenticeship.

2) Performing industry practice regularly at industry and guided well by technician will get good and optimal result. Students should get job at industry in accordance with their study field background.

3) In performing indutry practice, students should be guided by good mentor (instructures or technicians). In addition, students should look for problems at Industry and expected can help overcoming dan give solutions for advancement of industry.

4) Students in implementing industry practice should work seriously and learn in detail how the work process in industry, how to handle a job and tackle problems in order the systems can work well.

5) Students can look for the variety of problems that exist at industry to be used as topic of final project for completing their study.

6) Vocational teacher besides has vocational competence according to their field, he also must be able to provide that experience he gets while in the industry as an apprentice labor to be transferred to their students in SMK.

\section{References}

Alva Edy Tontowi, 2014, Development of Industry Incubator Based Learning, , Faculty of Engineering , Industry Technical Department, Gajah Made University, (Pengembangan Pembelajaran Berbasis Inkubator Industri) Fakultas Teknik Jurusan Teknik Industri UGM, Lontar Gajah Mada, Volume 1, no. 2 Juni 2004: http://www.google.co.id/url?sa=t\&rct=j\&q=\&esrc=s\&source=web\&cd=3\&ved=0CDAQFjAC\&url

Bukit Masriam, 2012. Strengthening TVET Teachers's Education through Teacher-Indusry Linkages, Proceeding ot the $2^{\text {nd }}$ UPI International Conference on TVET Bandung, Indonesia, 4-5 December 2012. 
Dittrich Joachim, Yunus Jailani Md, Spottl Geord, Bukit Masriam, 2009, Standardization in TVET Teacher Education, Peter Lang Internationaler Verlag der Wissenschaften.

European Commission, 2012, Apprenticeship Supply in the Member States of the European Union, 2012)

INAP Commission, 2012, An Architecture for Modern Apprenticeships, Standard for Structure, Organization and Governance, INAP Commission, 2012.

Indonesia Republic Act, No. 14, year 2005, About Teacher and Lecturer, 2006 (Undang-Undang RI No.14 tahun 2005 Tentang Guru dan Dosen, Bandung: Citra Umbara, 2006).

2000, Modern Apprenticeships, A Survey Report by The Training Standards Councils

RCP (Regional Co-operation Platform), 2011, Common statement on Vocational Teacher Education in Asia, Bangkok, 18-01-2011.

Moerwismadhi, 2012, Teaching Factory, a Concept to Sutainable Vocational Higher Education Institute, Manufacture Polytechnic (Politeknik Manufature Negeri) Bandung.

2013, Indonesia lacks 39,000 teachers (Indonesia Kekurangan 39.000,- Guru), Newspaper Sindo, June 2013 (Koran Seputar Indonesia, 26 Juni 2013,

,2014, Indonesian Manpower is ready to face AEC (ASEAN Economy Community), (Tenaga Kerja Indonesia Siap Hadapi AEC 2015) Newspaper Sindo, September 3, 2014 (Koran Seputar Indonesia, 3 September 2014).

Ratnata I Wayan, 2013, Enhancing The Image And Attractiveness of TVET, http://www/tvetonline.asia/issue/1/ratnata tvet1.

RCP, 2013, Vocational Teacher Education and Research as a Task and Challenge for the East and Southeast Asian Region, UNESCO Bangkok - Asia and Pacifik Regional Bureau for Education.

Samodra Y V, 2012, Production Based Education and Training (PBET), ATMI Polytechnic (Politeknik) Surakarta

Smith . E (2012), Good Practice in Apprenticeship Systems: Evidence from an International Study, $2^{\text {nd }}$ UPI International Conference on Technical and Vocational Education and Training Bandung, West Java, Indonesia, December 4-5, 2012

Sunaryo Kartadinata, 2014, Educational Quality Determines Advancement of Nation (Kualitas Pendidikan Tentukan Kemajuan Bangsa), Newspaper Sindo, April 17, 2014 (Koran Seputar Indonesia, 17 April 2014)

Sunaryo Kartadinata, 2014, Redesign of Education (Mendesain Ulang Pendidikan), Newspaper of Pikiran Rakyat, June 25, 2014 (Harian Umum Pikiran Rakyat, 25-6-2014).

Tjahyono, Anang (2012): Keynote Speech during Rembug Nasional SMK Membangun Bangsa (National discussion on SMK building the Nation), Universitas Pendidikan Indonesia, Bandung, 18.6.2012.

Yin, R.K., 1987. Case Study Research. California: Sage Publication Inc. 